\title{
Review of Literature on Involvement and Style of Parents towards Student Performance
}

\author{
Deegoda Gamage Indu Ramira Sumanasekera ${ }^{1}$, Junainah Abd Hamid ${ }^{2}$,Ali Khatibi ${ }^{3}$ and \\ S. M. Ferdous Azam ${ }^{4}$ \\ 1 Management \& Science University (MSU),indusumanasekera@gmail.com \\ 2 Management \& Science University (MSU) \\ 3 Management \& Science University (MSU) \\ 4 Management \& Science University (MSU)
}

\section{ABSTRACT}

Parents play a vital role as social actors in the development of children's academic achievement by motivating them. Their active participation in their children's learning process is quite important for them to influence their children for a better learning outcome. Parental involvement in literature has been defined in a variety of ways. Parental involvement is generally the involvement of parents in the children's education process with the aim of improving their academic as well as social well-being. These include various activities such as supporting and monitoring homework at home, attending school activities and attending parent and teacher interaction sessions, communicating with teachers, volunteering activities at school, and working with the community. For an every child, the school is often called as the second home, which helps molding a child to become a global citizen. The children are taught moral values and standards through interactions at school, also aiming at developing the knowledge and skills required for the labor market in future. Findings of research done on influence of parental involvement in the academic performance of the children shows that there is a significant relationship between the parental involvement and the student performance of the children. Active involvement of parents appears to have a greater impact on students' performance. A child's parental involvement begins at nursery level and then continues through the primary, the secondary and at the high school. Although it is important at every grade and throughout, yet it is known to be critical at the secondary schooling stage. There's a tendency of parents getting less involved in their children's education when their children becoming young adolescents.Many countries have examined the impact of parental involvement and parenting styles on student performance. As per the literature, lack of research attention has been given to the theoretical blend of parental involvement and parenting style towards students' academic performance in developing countries. Therefore, further research needs to be carried out.

Key words:Parental Involvement, Parenting Styles, Student Performance

Corresponding Author:Sumanasekera, D.G.I.R.

\section{PARENTAL INOLVEMENT}

Parent involvement is the volunteer service of parents at school or at home for the purpose of improving a child's education. Parent participation is a critical component of academic success and social development (Mautone et al., 2015; Yingqi, 2015) Parents that are active 
in their child's schools has shown positive effects including increased academic achievement, positive social behavior, augmented resources and social networking opportunities (Garbacz et al., 2015).

Parental involvement refers to a situation where parents are directly involved in the education of their children, they involve themselves and are involved by the school and teachers in the learning process of their children, and they fulfill their duties as parents in making sure that the learner is assisted in the process of learning as much as they possibly can. It does not just refer to parents enquiring about the performance of a learner in schools, but also in them taking a role in communicating with their children with the aim of having a healthy relationship with them, so that the process of encouraging, mentoring, leading and inspiring may be genuine (Clinton \& Hattie, 2013).

The transition to secondary school is a period with several developmental tasks, involving academic challenges, decision making processes, regulation of peer socialization and important vocational decisions (Brkovic, Kerestes, \& Levpuscek, 2014; Diogo, 2007; Ginevra, Nota, \& Ferrari, 2015), and for an adaptive transition, parents can act as and as protectors facilitators (Gordon \& Cui, 2012). In fact, parental behaviours (e.g. warmth, acceptance, support, involvement) as well as parent-child relationships(e.g. openness, closeness, warmth) have been touted as powerful tools to promote a positive socio-emotional, behavioural, and academic development (Garthe, Sullivan, \& Kliewer, 2015; Ginevra et al., 2015).

Nevertheless, among several parenting practices, parental involvement in school education is one that is most important regarding educational outcomes and future success (Wang et al., 2014; Wang \& Sheikh-Khalil, 2014; Wilder, 2014).

Joyce Epstein as a researcher has drawn six types of parental approach, coined as a model, and they are parenting, communication, volunteering, learning at home, decision-making, and collaborating with community (Epstein, 1987, 1995, 2001, and 2011). Further, through the model Epstein emphasizes the importance of parental involvement to be effectively developed in a child and it also make out the diversity of actions needed to be taken by parents in supporting the process of their child's development (Peiffer, 2015).

Parents' involvement in school life was frequently related to academic success, especially in the first levels of schooling, and parents recognized that "the greater the presence and involvement of parents in school the greater the percentage of success". However, parents also assumed that there was a great decrease of involvement in secondary school and explored some of the reasons for this; parental involvement was quite different. Parenting depended also on the help that the school could provide to the families, aiming to increase parents' understanding about their children's development and academic achievement (Costa \& Faria, 2017).

Apart from the academic achievement of a student, parental involvement also affects change in behavior with positive effects. Student's ability to self- regulation in the daily routine of life is also improved by the parental involvement (Brody, Flor, and Gibson, 1999).

\section{PARENTING SYLE}

A parenting style is a psychological construct representing standard strategies that parents use in their child rearing. There are many differing theories and opinions on the best ways to rear children, as well as differing levels of time and effort that parents are willing to invest. One of the best known theories of parenting style was developed by Diana Baumrind(1965, 1971, 1978, and 1996). She proposed that parents fall into one of three categories: authoritarian (telling their children exactly what to do), permissive (allowing their children to do whatever they wish), or authoritative (providing rules and guidance without being overbearing). The 
theory was later extended to include negligent parents (disregarding the children, and focusing on other interests).

Some empirical studies show that the authoritative parenting style was associated with adolescents' academic achievement (Checa and Gutierrez, 2018). In some, the association between parenting and academic achievement differed from maternal and paternal reports: mothers' parenting styles were not associated significantly with adolescents' academic achievement. It is clear that the parenting style adopted within the family has an impact on children and adolescents academic achievement. The attitudes that parents have towards their kids have an effect on the involvement they show in the school, as well as in the development of skills and abilities needed to cope with school demands. Parenting styles are also a reflection of the society parents belong to, which transmits values, expectations, behavior patterns, belief system and guidelines about optimal and deficient parenting (Checa and Gutierrez, 2018). Baumrind (1991) retained that authoritative parenting style is more balanced parenting style and creates a supportive home environment for children's academic and psychological development compared to authoritarian and permissive parenting styles (Rabgay, 2015).

\section{STUDENT PERFORMANCE}

Student's performance in school is evaluated in a number of ways. For regular grading, students demonstrate their knowledge by taking written and oral tests, carrying out presentations, completing homework and participating in class activities and discussions. Teachers evaluate in the form of letter or number grades and offer comments to describe how well a student has done or back up the specific grade that was given. Additionally, in a written assignment, the teacher may also offer feedback and guidance on improving the writing. At the state level, students are evaluated by their performance on standardized tests geared toward specific ages and based on a set of achievements students in each age group are expected to meet.

It is very important for all stakeholders in the educational system to identify the factors affecting student's academic success. A study conducted by Damayanthi(2018), revealed that parental factors and student self-studying as the most influential factors at student level for their academic performance. Various attempts have been made by researches to investigate the determinants of student performance, but consensus hasyet to be achieved concerning factors impacting student academic performance, and the findings of these various studies are in mixed nature (Athurupane, Nomura and Shojo, 2018).

Many students cannot learn effectively as a result of not been encouraged. The finding of the studies shows that the Parental involvement (parenting, communicating, learning at home, decision making) has a positive impact towards student performance (Ubale, Abdurrahman and Abdullah, 2015). Since the motivation deals with the human behavior and cognitive development, parents should be involved in the educational development of their children that will eventually enable them to be more productive in the society (Ubale et al., 2015). Further, Arulmoly and Elankumaran (2017) also examined that parental involvement has a significant relationship towards their children's performance at the school.

\section{PARENTALINVLVEMENT AND STUDENT PERFORMANCE}

Most parents assumed that their children could not be educated merely on the school environment and that home environment would have a lasting impact on school education. Therefore, many parents recognize the importance of school and home collaboration in educating their children.

Findings of research done on the influence of parental involvement in the academic performance of the children shows that there is a significant relationship between the parental 
involvement and the student performance of the children (Yaseen, Zaman and Rasheed, 2017, Ambachew, Amare and Geleta, 2018, Simweleba \& Serpell, 2020). However, parents' active involvement is more influential with students' performance than the other socioeconomic factors. While parental involvement is important at every grade level, it is critical at the secondary school stage because parents of young adolescents have a tendency to become less actively involved in their children's reach upper secondary stage in their education (Oates, 2017).

Moreover, the existing researches have revealed the importance of parental involvement towards student performance. Mutodi and Ngirande (2014) argues Three parental involvement constructs, that is, parenting, parent -teacher communication and home and family support were found to be positively related to performance. Studies conclude that the home and family support is the most significant factor that determines a learner's performance.

The parents who involve themselves in the children's education at home, their children as a result, show good performance at school. Akbar, Chisthi \& Younes, (2017) stated that the Parental involvement is found statistically significantly contributing towards the outcome of Student Performance. The study helps us to accept that there is a relationship between parental involvement and their children's academic achievement. Furthermore, studies carried out by Hussain, Javaid, Parveen \& Iqbal (2018) and Ambachew, Amare, \& Geleta (2018) revealed that there is a strong positive and significant relationship between parental involvement and academic performance of students. Similarly, studies carried out Akbar (2015); , Topor et al., (2010) reviles that Parental involvement (PI) is found to be statistically significantly contributing towards the outcome of Students' scores. Research studies carried out by Jaiswal and Choudhuri (2017) suggests that when parents are actively involved in their children's educational activities, show affection to their children, participate in school events, democratic and responsive in nature, and keep positive educational expectation then students' academic performance becomes higher.

Based on Parka and Holloway (2017) studies, stated that the effects of school-based parental involvement on academic achievement at the child achievement in mathematics significant. Parental involvement became more strongly related to mathematics and reading achievement as children move through the grades. Providing information on how schools function, how to support learning, and how to access educational resources is another way to encourage parents to become more involved in school-based activities (Park and Holloway, 2013). Further, the studies confirm that parental involvement as the most powerful predictor of, particularly for low socioeconomic families, is the creation of a school environment where parents feel welcomed and valued by educators (Walker, Hoover-Dempsey, \& Sandler, 2007; Hoover-Dempsey, \& Sandler, 1997; Park \& Holloway, 2013; Baquedano-Lopez, Alexander, \& Hernandez, 2013)

There are various studies which provide empirical evidence on the positive impacts of the parental involvement and the student performance, in developing countries as well. In a study carried out in Ghana by the researchers Amponsah, Milledzi, Ampofo and Gyambrah (2018) reviled that there is a significant positive relationship between parental involvement and students' academic performance. Their findings revelries that parental involvement through homework, creating a learning environment for studying at home, motivating and setting realistic and high expectations for children enhances academic performance. Hence, parents as the prime educators and the first agents of socialization and exposing children to the social and academic world should play a leading role in supporting their children's education. Thus, for their children's educational attainment parents should set high and realistic expectations, to motivate their children to perform well academically. 
By establishing and enforcing the rules and regulations regarding school and home activities as well as providing opportunities and environment conducive for learning parents should also ensure home supervision. Schools should encourage Parent-Teacher Association (PTA) sessions to be conducted to educate and assist parents to develop better parenting skills (Amponsah, Milledzi, Ampofo and Gyambrah, 2018).

Another study carried out in Ethiopia, Ambachew, Amare, and Geleta, (2018) argue that there is a strong relationship between parental involvement and academic performance. Further, it significantly predicts student academic achievement motivation. On the other hand, pointed out that there is limited study on the relationship between parental involvement and academic achievement of secondary school students as majority of the research in this area has been conducted exclusively with elementary school students (Simweleba \& Serpell, 2020).

Parents should devote their time, effort, resources on their children's schooling to enhance their academic performance. They should actively participate on their children's schooling. Spend more time with their children, pay attention and follow up with their children to complete assignments, homework, note books and by providing rewards to motivate them, discuss on school activities, expectations of academic achievement, and the importance of achieving good results (Assefa and Sintayehu, 2019; Grolnick, 2014).

Another study has shown that the level of parental involvement focused on four main aspects as learning environment at home, social interaction with child, communication with child and support towards child excellence. Thereby, parents realize the importance and take action in providing an appropriate learning environment for children such as providing study area and reference books, have a conversation with the child, enquire child's activities and discuss their problems. Thus, concludes as there is positive relationship between parental involvement and students' performance (Ahmad et al., 2017). Research carried out by White (2017) indicated there are benefits of parental involvement (Fan et al. 2012; Green et al., 2007; Williams \& Bryan, 2013) that can positively influence student performance.

Mahuro and Hungi (2016) adopt two of the six types of parental involvement presented in the Epstein parental involvement model, parenting and communication with the school. They conclude as these types of involvement have contributed to their children an advantage towards academic achievement.

However, some of the previous studies on the relationship between parental involvement and student performance have delivered mixed and weak findings. Several studies have shown that parental involvement in children's academic education tends to decrease across schooling, moreover parental involvement changes throughout school (Jeynes, 2011; Costa and Faria, 2017; Wijsman et al., 2018).

On the other hand, father-child attachments were uniquely predictive of children's positive and negative school outcomes Holmes and Huston, 2010), although predictive relations varied depending of the specific outcomes. Fathers' school-based, but not home-based, involvement was significantly and uniquely predictive of children's negative attitudes towards school (Fatherhood Institute, 2010; Flouri, 2006). Both home-based and schoolbased educational involvement were negatively related to school problems but positively related to academic self-concept and school achievement, although associations were weaker than expected (Hoover-Dempsey \& Sandler, 2005; Walker et al., 2009). In US, father educational involvement was related to fewer school problems, greater knowledgeable/school status, and higher school achievement. In the Taiwan, father involvement was inversely related to children's school problems, but not knowledgeable/school status or school achievement (Newland and Chen, 2013). Hill and Tyson's analysis (2009) also found that school-based involvement was consistently related to children's school achievement, while home-based involvement was not. 
While parental involvement has been found to be related to increased academic performance, the mechanisms through which parental involvement applies its impact on a student's academic performance are not yet fully understood (Collins, Juma and Murundu (2019). Today, the family structure is quite different, one parent as the bread winner does not exists. With the new family setting the financial demand today, many parents are not able to support their children's education when it comes to parental involvement (Burns, 2010). Therefore, it can be said that the relationship among parental involvement and student academic performance is questionable because of the inconsistent findings of studies related to this relationship (Sulaimani \& Henning, 2020).

The inconsistent findings of the parental involvement construct sets difficult to arrive at any general conclusion. Some research studies revealed a positive relationship between parental involvement and student academic achievement (Barnard, 2004; Christenson et al., 1992; Singh et al., 1995) and others reported no measurable to negative effect of parental involvement on student academic achievement (Keith at al., 1986; Tokac \& Kacayoruk, 2012).

Moreover, Lam and Ducreux (2013), in turn, found no significant association among parental help, monitoring and pressure and academic achievements. There are a number of dimensions that are yet to be tested together as the dimensions of parental involvement affecting the student performance. There is a gap in knowledge relating to the parental involvement and student performance (Juma, Muramdu, Colins, 2019). Thus, there is a need for research to explore further on the relationship between parental involvement and student performance (Juma, Muramdu, Colins, 2019; Sulaimani \& Henning, 2020). Although there's a declining trend in parental involvement towards student performance as children proceed to high school (Wijsman et al., 2018), it is still questionable because of the inconsistent findings of studies related to this relationship. Thus, there is a need for research to explore further (Sulaimani \& Henning, 2020).

\section{PARENTING STYLE AND STUDENT PERFORMANCE}

Over the years parenting styles and behaviors has evolved. The three parenting styles namely; authoritative, authoritarian and permissive (Baumrind, 1966, 1967, 1978, 1991) are used to determining academic success in literature from western cultures (Masud et al., 2015; Pinquart, 2016; Checa et al., 2019). Evidence from cultural similarities with Pakistan shows varied findings. A study from Iran shows support for the authoritarian parenting style similar to Pakistan (Rahimpour et al., 2015). Determining academic performance of students in the West and European countries the authoritative parenting style is the dominant and most effective style applied, while Asian counties show more favorable results for academic performance for the authoritarian style (Masud et al., 2015). However, high parenting style of the father adds a significant contribution to obtain higher academic grades by their children. Thus, father's role plays an important part in determining their children's academic outcome in Asian cultures (Masud et al., 2015).

A number of studies have been conducted on the relationship between parenting style and student academic performance (Kösterelioğlu, 2018). Most scholars have found a positive impact of parenting styles on student performance. Lerdponkulrat et al. (2012) reported students who perceived their parents as authoritarian had higher performance. Mahasneh (2014) reported positive relationships between parenting style and academic success on authoritarian and permissive parenting styles and, the authoritative parenting style is the best predictor of academic achievement.

According to Purificación C, Alicia (2018) and Orhan-Özen (2017) parenting style has a positive effect on student performance. Jeynes (2010) indicated that parenting style is an important component of parental involvement because it helped to produce a positive home 
life for the child. The home-to-school relationship is significant because it can expand and redefine the whole concept of parental involvement (Seginer and Mahajna, 2018). Xu, Dai, Liu and Deng (2018) examined how children at near adolescents' age perceived parental psychological control and autonomy based on their parenting style towards academic achievement. Study carried out in Bhutan (Rabgay, 2015), found that there were differences in students' academic performance due to differences in parenting style. It revealed that, out of the three parenting styles, namely authoritative, authoritarian and permissive, found that authoritative parenting results in better students' academic performance compared to students whose parents had an authoritarian and permissive style of parenting. In the same way, Uma and Manikandan (2014) noted that parents style play a significant role in determining the level of academic performance among adolescents. Thus, it is essential that parents should be equipped with appropriate knowledge and skills so that they can provide better guidance for their adolescents' positive development especially in academic aspects.

\section{CONCLUSION}

Parental involvement is partaking of parents in their children's educational process with an aim of improving their academic and social well-being. Education is a power that influences individuals' lives. Parents' participation in the education process can increase the performance of their children. The more parents engage with their children, the higher scores their children achieve.

Parenting has been one of the main focuses in developmental and educational fields and much theories has been advanced about parents' personal and social factors that better foster children's growth and development. Particularly in adolescence there are several developmental and contextual transformations as well as challenges that affect not only adolescents but also their parents. As per the literature, parental involvement is represented by six dimensions such as parenting, parenting, facilitating learning at home, communicating with the school, volunteering at the school, participating in school decision making and collaborating with the community, are well documented.

Parenting styles are the manner in which parents rear their children. Parents want their children to grow into socially mature individuals. To discover the best way to accomplish this they adopt varying parenting styles. As per the literature, parenting styles have identified as three dimensions, namely; authoritative, authoritarian and permissive. These three dimensions such are well documented in the literature.

Both parental involvement and parenting styles affect student performance as per the literature.Further, it significantly predicts student academic achievement motivation.Parents as the prime educators and the first agents of socialization and exposing children to the social and academic world should play a leading role in supporting their children's education. Lack of parent's attention affects better performance of their children at examinations. If children are motivated by their parents by getting involved in their learning journey, children tend to continue to perform successfully at their educational attainments.

Several countries have examined the impact of parental involvement and parenting styles on student performance. Yet, as per the literature, lack of research attention has been given to the theoretical blend of parental involvement and parenting style towards students' academic performance in developing countries. Student performance is viewed as one of the key elements in developing the human capital of a country. Therefore, further research needs to be carried out, especially in developing countries.

\section{REFERENCES}

1. Abdul G. K. and Kurukkan A. (2014). Construction and Validation of Scale of Parenting Style. Guru Journal of Behavioral and Social Sciences 2(4) 
2. Ahmad, N.A, Hassan, S.A., Ahmad, A.R., Chua, L.N., and Othman, N. (2017). Parental Involvement In Learning Environment, Social Interaction, Communication, and Support Towards Children Excellence At School. Journal of Sustainable Development Education and Research.Vol. 1, No.1, 2017, pp. 83-90

3. Akbar T. (2015) Parental Involvement and Students' Academic Achievement: A Quantitative Study. City University of Science and Information Technology, Peshawar.

4. Alkış, N. (2015). The influence of personality traits, motivation and persuasion principles onacademic performance (Unpublished Doctoral Dissertation). Middle East Technical University, Ankara.

5. Aluçdibi, F., \& Ekici, G. (2012). The effect of biology teachers' classroom management profileson the biology course motivation level of the high school students. Hacettepe University Journal of Education, 43, 25-36.

6. Assefa A. and Sintayehu B. (2019). Relationship between Parental Involvement and Students' Academic Achievement in Model Primary and Secondary School of Haramaya University, East Hararghe Zone, Oromia Regional State, Ethiopia. Achieve International Journal of Education \& Literacy Studies. 2019, 7(2).

7. Akpur, U. (2015). The relationship pattern between English prep school students' academicachievement and their academic motivation, anxiety and attitudes. Yıldız Teknik University, İstanbul.

8. Alkış, N. (2015). The influence of personality traits, motivation and persuasion principles onacademic performance. Middle East Technical University, Ankara.

9. Alyssia R, Gonzales D, Patricia PW (2005) Underutilization of parentinvolvement in the schools. School Community Journal 17: 85-88.

10. Ambachew T., Amare, M., \& Geleta S. (2018). The relationship between parent involvement and students' academic achievement motivation: the case of East Hararghe zone senior secondary and preparatory schools. Scholars Journal of Arts, Humanities and Social Sciences, 6(7), 1448-1452.

11. Amponsah M. O., Milledzi E.Y., Eric Twum Ampofo E.T and Gyambrah M., (2018). Relationship between Parental Involvement and Academic Performance of Senior High School Students: The Case of Ashanti Mampong Municipality of Ghana. American Journal of Educational Research. 2018, 6(1), 1-8.

12. Barnard, W.M. (2004). Parent involvement in elementary school and educational attainment. Children and Youth Services Review, 26, 39-62.

13. Baquedano-Lopez, P., Alexander, R. A., \& Hernandez, S. J. (2013). Equityissues in parental and community involvement in schools: Whatteacher educators need to know. Review of Research in Education, 37,149-182.

14. Bates, C. C., D’Agostino, J. V., Gambrell, L., \& Xu, M. (2016). Reading recovery: Exploring theeffects on first graders' reading motivation and achievement. Journal of Education for Students Placed at Risk, 21, 47-59.

15. Bhat M., Joshi J. and Wani I. (2016), Effect of Socio Economic Status on Academic Performance of Secondary School Students. The International Journal of Indian Psychology. 3 (4), 56

16. Brittany C, Mary N (2005) The relationship between parental involvement,student. Motivation and academic achievement. International Journal of Learning 16: 459-470.

17. Caño K., Cape M., Cardosa J.,Carolyn Miot, Gee Rianne Pitogo and Cherrie Mae Quinio (2016). Parental Involvement on Pupil's Performance: Epstein's Framework. Journal of New Horizons in Education,6(4). https://www.tojned.net/journals/tojned/articles/v06i04/v06i04-16.pdf 
18. Chaudhry A. Q, Hassan S. M., Khaliq M. A, and Agha Q. (2015). Parent'sInvolvement in their Child Academic Achievement, Pakistan Vision 15(2): 117-125. http://pu.edu.pk/images/journal/studies/PDF-FILES/Artical-6_v16_1.pdf

19. Checa, P., Abundis-Gutierrez, A., Pérez-Dueñas, C., and Fernández-Parra, A. (2019). Influence of maternal and paternal parenting style and behavior problems on academic outcomes in primary school. Front. Psychol. 10:378. doi: 10.3389/fpsyg.2019.00378

20. Cherry, K. (2016). Motivation: Psychological factors that guide behavior. Retrieved from https://www.verywellmind.com/what-is-motivation-2795378

21. Costa, M., \& Faria, L. (2017). Parenting and Parental Involvement in Secondary School. Vol. 27, No. 67, 28-36.

22. Christenson, S. L., Rounds, T., and Gorney, D. (1992). Family factors and student achievement: An avenue to increase students' success. School Psychology, 7, 178-206.

23. Damayanthi B. (2018), Academic Performance of Students: the Effect of Class Room Level Factors and Private Tutoring.American Journal of Educational Research, 6(3) (2018): 262-269. doi: 10.12691/education-6-3-13.

24. Deci, E. L., \& Ryan, R. M. (2016). Optimizing students' motivation in the era of testing andpressure: A self-determination theory perspective. In Building autonomous learners.Singapore: Springer.

25. Deepika S. and Sushma S., (2018) Relationship between motivation and academic achievement.International Journal of Advances in Scientific Research, 4(1), 01-05.

26. De Silva, A. D. A., Khatibi, A., \& Azam, S. F., (2017). Do thedemographic differences manifest in motivation to learnscience and impact on science performance? Evidencefrom Sri Lanka. International Journal of Science and Mathematics Education, 1-21.

27. De Silva, A. D. A., Khatibi, A., \& Azam, S. F.,(2018). What factors affect secondary students' performance in science in the developing countries? A conceptual model for an exploration. European Journal of Education Studies, 4 (6), 80-100.

28. Diseth, A., Pallesen, S., Brunborg, G. S., \& Larsen, S. (2010). Academic achievement among first semester undergraduate psychology students: the role of course experience, effort, motives and learning strategies. Higher Education, 59(3), 335-352. https://doi.org/10.1007/s10734-009-9251-8

29. Epstein, J. L. (1995). School and family connections: Theory, research and implications for integrating sociologies of education and family. Marriage and Family Review, 15, 99126.

30. Epstein, J. L. (2011). School, family, and community partnerships: Preparing educators and improving schools (2nd ed.). Philadelphia, PA: Westview Press.

31. Erdoğan, B. (2013). The effect of adaptive learning management system on student's satisfaction, motivation and achievement in online learning. Ankara University, Ankara.

32. Fan, W., \& Williams, C.M. (2010). The effects of parental involvementon students' academic self-effi cacy, engagement and intrinsicmotivation. Educational Psychology: An International Journal of Experimental Educational Psychology, 30(1), 53-74. doi:10.1080/01443410903353302

33. Gafoor K. A., Kurukkan A., (2014) Construction and Validation of Scale of Parenting Style.Guru Journal of Behavioral and Social Science 2 (4), 315-323

34. Goni U., \& Bello S., (2016). Parental socio-economic status, self-concept and gender differenceson students' academic performance in Borno state colleges of education: Implications for counseling. Journal and Education Practice, 7(14), 2222-1735. 
35. Grolnick W. S., (2014). Mothers' motivation for involvement in their children's schooling: mechanisms and outcomes. Motiv Emot (2015) 39:63-73 DOI 10.1007/s11031-014-9423-4

36. Guay, F., Ratelle, C., Larose, S., Vallerand, R. J., \& Vitaro, F. (2013). The number ofautonomy-supportive relationships: Are more relationships better for motivation, perceivedcompetence, and achievement? Contemporary Educational Psychology, 38(4), $375-382$.

37. Hafiz M. W. R., Tehsin F., Malik M. S., Saleem M., Khan M.A., (2013). Parental Involvement and Academic Achievement; A Study on Secondary School Students of Lahore, Pakistan. International Journal of Humanities and Social Science (3) 8, 209-203.

38. Hamid M., Shakil A.M., Ali A.J., Ahmad J., (2016) Relationship between parenting styles and academic performance of adolescents: mediating role of self-efficacy. 17 (1), 121131

39. Hasan M., (2016) Correlates of Parental Support and Academic Achievement of Male and Female Secondary School Students. The International Journal of Indian PsychologyISSN 2348-5396 (e) | ISSN: 2349-3429 (p) Volume 3, Issue 2, No.7, DIP: 18.01.135/20160302 ISBN: 978-1-329-92551-9

40. Hayenga, A. O., \& Corpus, J. H. (2010). Profiles of intrinsic and extrinsic motivations: Aperson-centered approach to motivation and achievement in middle school. Motivation and Emotion, 34(4), 371-383.

41. Hill, N.E., \& Tyson, D.F. (2009). Parental involvement in middle school: A meta-analytic assessmentof the strategies that promote achievement. Developmental Psychology, 45(3), 740-763.

42. Hejazi E., (2018). The Mediation Role of Intrinsic Motivation in Relationship Between Perceptions of Parenting Styles with Academic Resilience, Research Gate.com

43. Holmes, E.K., \& Huston, A.C. (2010). Understanding positive father-child interaction: Children's, fathers', and mothers' contributions. Fathering: A Journal of Theory, Research, \& Practice about Men as Fathers, 8(2), 203-225.

44. Jaiswal, S., Choudhuri, R. (2017). A Review of theRelationship between Parental Involvementand Students _Academic Performance.International Journal of Indian Psychology, 4(3), 110-123.

45. Kapinga S., (2014). The impact of parental socio economic status on students' academicachievement in secondary schools in Tanzania. International Journal of Education, 6 (4), 1948-5476.

46. Keith, T. Z., Keith, P. B., Troutman, G. C., \& Bickley, P. G. (1993). Does parental involvement affect eighth-grade student achievement? Structural analysis of national data. School Psychology Review, 22, 474-496.

47. Kian, T., Yusoff, W., \& Rajah, S. (2014). Motivation for generations' cohorts: An organizationaljustice perspective. International Journal of Management Sciences, 11(2), $536-542$.

48. Kocayörük E., (2016). Parental Involvement and School Achievement. International Journal of Human Behavioral Science. 2(2), 1-5.

49. Koca F.,(2016). Motivation to Learn and Teacher-Student Relationship. Journal of International Education and Leadership. Volume 6 Issue 2 Summer 2016ISSN: 21617252

50. Kösterelioğlu I., (2018). Effects of Parenting Style on Students' Achievement Goal Orientation: A Studyon High School Students. Educational Policy Analysis and Strategic Research, V 13,N 4, 91-107. 
51. Lawrence A. and Barathi C. (2016), Parental Encouragement in Relation to Academic Achievement of Higher Secondary School Stdents. International Journal of Advance Research and Innovative Ideas in Education (2016). 2(6) 1234-1239

52. Liu, W. C., Wang, C. K., \& Ryan, R. M. (2016). Understanding motivation in education:Theoretical and practical considerations. In Building autonomous learners. Singapore:Springer.

53. Liu R. and Chiang Y.(2019) Who is more motivated to learn? The roles of family background and teacher-student interaction in motivating student learning. The Journal of Chinese Sociology. (6)6, 1-27

54. Masud H., Shakil A. M., Jan F.A., Jamil. F.A., (2016). Relationship between parenting styles and academic performance of adolescents: mediating role of self-efficacy. Asia Pacific Education Review, 10.1007/s12564-015-9413-6

55. Matejevic M., Jovanovic D. \& Jovanovic M., (2014). Parenting style, involvement of parents in school activities andadolescents' academic achievement. Procedia - Social and Behavioral Sciences 128 ( 2014 ) 288 - 293

56. Masud S., Syed H M., Nada Q Q., Khan F., Khan S., Khan N M., (2019). Academic Performance in Adolescent Students: The Role of Parenting Styles and SocioDemographic Factors - A Cross Sectional Study From Peshawar, Pakistan. Front. Psychol., Retrieved from https://doi.org/10.3389/fpsyg.2019.02497

57. Mutodi P. \& Ngirande H., (2014). The Impact of Parental Involvement on Student Performance:A Case Study of a South African Secondary School. Mediterranean Journal of Social SciencesMCSER Publishing, Rome-Italy, Vol 5 No 8 p 279-289

58. Mubeen S. \& Reid N., (2014). The Measurement of Motivation with Science Students. EUROPEAN JOURNAL OF EDUCATIONAL RESEARCH Vol. 3, No. 3, 129-144

59. Newland, L.A., \& Chen, H., (2013) Associaions Among Father Beliefs, Perceptions, Involvement, Child Attachment in the Schooloutcome in US and Thaiwan, FATHERING, VOL. 11, NO. 1, WINTER 2013, p 3-30.

60. Orhan-Özen S., (2017) The Effect of Motivation on Student Achievement.Springer International Publishing AG 2017E. Karadağ (ed.), The Factors Effecting Student Achievement,DOI 10.1007/978-3-319-56083-0_3

61. Park, S., \& Holloway, S. D. (2013). No parent left behind: Predicting parentalinvolvement in adolescents' education within a socio-demographicallydiverse population. The Journal of Educational Research, 106, 105-119.

62. Peiffer, G. (2015). The Effect of Self-efficacy on Parental Involvement at the Secondary School Level. Doctoral Dissertation, University of Pittsburgh.

63. Purificación C, Alicia A-G. Parenting Styles, Academic Achievement and the Influence of Culture. Psychol Psychother Res Stud.1(4). PPRS.000518.2018. DOI: 10.31031/PPRS.2018.01.000518

64. Nejla G., Ceren O. and Hasan E, (2017). Investigation Number Sense TestAchievements of Middle School Students According to Different Variables. American Journal of Educational Research, 5(9): 1004-1008. doi: 10.12691/education-5-9-13.

65. Rabgay T., (2015). A Study of Factors Influencing Students' Academic Performance in aHigher Secondary School in Bhutan. Rabsel - the CERD Educational Journal. Vol. 16, Issue - 2,pp 74-94

66. Ruholt R, Gore J., Dukes K. (2015). Is Parental Support or Parental InvolvementMore Important for Adolescents? Eastern Kentucky University(2015), 28 (1).

67. Saifi, S. \& Mehmood, T. (2011). Effects of sosioeconomis status on student's achievement. International Journal of Social Science and Education, 1(2), 119-124. 
68. Şen, M. (2006). Effects of English lessons, based on multiple intelligence theory, on students'motivation, self-efficacy, self-esteem and multiple intelligences (Unpublished Master dissertation).Ankara University, Ankara.

69. Singh, K., Bickley, P, Trivette, P., Keith, T. Z., Keith, P. B., \& Anderson, E. (1995). The effects of four components of parental involvement on eighth grade student achievement: Structural analysis of NELS-88 data. School Psychology Review, 24, 299-317.

70. Steinmayr, R., Meißner, A., Weidinger, A. F., \& Wirthwein, L. (2014). Academic achievement. Oxford Bibliographies. doi, 10, 9780199756810-0108.

71. Stavrulaki E., Li M. \& Gupta J., (2019). Perceived parenting styles, academic achievement, and life satisfaction of college students: the mediating role of motivation orientation. European Journal of Psychology of Education. 10.1007/s10212-020-00493-2

72. Suleman, Q., Hussain, I., Khan, U. F., \& Nisa, U. Z. (2012). Effects of parental socio economic status on the academic achievement of secondary school students in Karak district, Pakistan. International Journal of Human Resource Studies, 2(4), 2162-305

73. Tokac, U., \& Kocayörük, E. (2012). Exploring Effects of Parent Involvement on Student's Achievement. International J. Soc. Sci. \& Education, 2(2), 257-263.

74. Jaiswal K. S, \& Choudhuri R., (2017). A Review of the Relationship between Parental Involvement and Students' Academic Performance. The International Journal of Indian Psychology, ISSN 2348-5396 (e), ISSN: 2349-3429, p 120-123

75. Miñano, P., \& Castejón, J.L. (2011). Cognitive and motivational variablesin the Academic achievement in language and mathematics subjects:A structural model. Revista de Psicodidáctica, 16(2), 203-230.

76. Miñano, P., Gilar, R., \& Castejón, J.L. (2012). A structural model ofcognitivemotivational variables as explanatory factors of academicachievement in Spanish Language and Mathemathics. Anales de Psicología, 28(1), 45-54.

77. Murugupillai R., Wanigasinhe J., Muniyandi R., \& Arambepola C., (2015). Parental concerns towards children and adolescents with epilepsyin Sri Lanka-Qualitative study. Published by Elsevier Ltd on behalf of British Epilepsy Association.Seizure 34 (2016) 611

78. Núñez J. C., Regueiro B., Fernández N. S., Valle N., Piñeiro I., Rodicio M.L., (2018) Student Perception of Teacher and Parent Involvement in Homework and Student Engagement: The Mediating Role of Motivation. Frontiers in Psychology, (10) 1384, 116

79. Oates T., (2017). Building effective parental involvement inmiddle schools: The parents' perceptions (Doctoraldissesrtaion). Retrieved from http://commons.cuportland.edu/cgi/viewcontent.cgi $?$ article $=1070 \&$ context $=e d u d i s s e r t a t i$ on

80. Simpkins, S.D., Fredricks, J.A., \& Eccles, J.S. (2012). Charting the Eccles'expectancyvalue model from mothers' beliefs in childhood to youths'activities in adolescence. Developmental Psychology, 48, 1019-1032.doi: 10.1037/a0027468

81. Tanvir M., Bukhari F., Umbreen K. and Fayyaz S., (2016). Parenting Style and Its Effects on Academic Achievement of Children. SAMANM Journal of Business and Social Sciences (4) 1

82. Tahiroğlu, M., \& Aktepe, V. (2015). Validity and reliability study on the motivation scale formdesigned for 4th and 5th grade social studies course. International Periodical for the Languages, Literature and History of Turkish or Turkic, 10(3), 907-932. 
83. Tarekegn A., Misganaw A., Sitota G (2018) The Relationship between Parent Involvement and Students' Academic. Achievement Motivation: the case of East Harerge Zone Senior Secondary and Preparatory Schools. Scholars Academic and Scientific Publishers. 1448-1452

84. Taylor et al., (2014), Cortina, M. A., Stein, A., Kahn, K., Hlungwani, T. M., Holmes, E. A., \& Fazel, M. (2016). Cognitive styles and psychological functioning in rural South African school students: understanding influences for risk and resilience in the face of chronic adversity. Journal of adolescence, 49, 38-46. https://doi.org/10.1016/j.adolescence.2016.01.010

85. Ubale AZ, Abdurrahman T, Abdullah AH (2015) A Relationship between Parental Involvement and Intrinsic Motivation on Learning IslamicEducation. Arts Social Sci J 6: 115. doi:10.4172/2151-6200.1000115

86. Uma K. \& Manikandan K., (2014). Parenting Style as a Modertor of Locus of Control, Slef Esteem and AcademicStress among Adolescents. SCHOLARS WORLD-IRMJCR Volume. II, Issue III, July 2014. pp 64-73

87. Ural, M. N. (2009). The effect of entertaining and motivational properties of educational games toacademic achievement and motivation. Anadolu University, Eskişehir.

88. Valle, A., Regueiro, B., Núñez, J. C., Rodríguez, S., Piñeiro, I., and Rosário,P. (2016). Academic goals, student homework engagement, and academicachievement in elementary School. Front. Psychol. 7:463. doi: 10.3389/fpsyg.2016.00463

89. Walker, J.M.T., Wilkins, A.S., Dallaire, J.P., Sandler, H.M., \& Hoover-Dempsey, K.V. (2005).Parental involvement: Model revision through scale development. Elementary School Journal, 106, 85-104.

90. Wigfield, A., Tonks, S., and Klauda, S. L. (2016). "Expectancy-value theory," in Handbook of Motivation in School, 2nd Edn. eds K. R. Wentzel and D. B. Mielecpesnm (New York, NY: Routledge), 55-74.

91. Wijsman L.A., Warrens M.J., Saab N., van Driel J.H., Westenberg M., (2016). Declining trends in student performance in lowersecondary education. Springerlink.com. Eur J Psychol EducDOI 10.1007/s10212-015-0277-2

92. World Bank in Sri Lanka (2015). The School Family Works Together to Improve Sri Lankan Student Learning Experience in Public Sector Schools. Retrieved from http://www.worldbank.org/en/news/feature/2015/05/15/the-school-family-works-togetherto-improve-srilankan-student-learning-experience-public-sector-schools

93. Wijesman L., Warrens M., Saab N., Van Direl J., Westenberg P. (2015), Declining trends in student performance in lowersecondary education. Eur J Psychol Educ 31:595-612

94. Yaseen, M., Zaman, S., \& Rasheed, N. (2017). An Empirical Study on the Role of Parents in Academic Achievement of Children in Private Schools of Karachi, 84-92.

95. Yilmaz E., Sahin M., Turgut M., (2016). Variables Affecting Student Motivation Based on AcademicPublications, Journal of Education and Practice, 8 (12), 112-120

96. York T. T., Gibson C., and Rankin S., (2015). Defining and Measuring Academic Success. Practical Assessment, Research \& Evaluation, 20(5), 2.

97. Zahedani Z., Rezaee R., Yazdani Z., Bagherai S. and Nabeiei P., (2016). The influence of parenting style on academic achievement and career path. Journal of Advances in Medical Education \& Professionalism. 4(3), 130-134.

98. Zong X., Zhang L., and Yao M., (2017). Parental involvement andChinese elementary students' achievement goals: the moderating role of parenting style,Educational StudiesDOI: 10.1080/03055698.2017.1373634 